\title{
Interaction of cyanine dyes with nucleic acids. 2. Spectroscopic properties of methyleneoxy analogues of Thiazole Orange
}

\author{
Sergiy M. Yarmoluk*, Vladyslava B. Kovalska, Tetyana V. Smirnova ${ }^{\mathfrak{4}}$, \\ Mykola P. Shandura ${ }^{1}$, Yuriy P. Kovtun ${ }^{1}$, Gennadiy Kh. Matsuka \\ Institute of Molecular Biology and Genetics, National Academy of Sciences of Ukraine \\ 150 Zabolotnogo str., 252143, Kyiv, Ukraine \\ ${ }^{1}$ Institute of Organic Chemistry, National Academy of Sciences of Ukraine \\ 5 Murmanska str., 253660, Kyiv, Ukraine
}

\begin{abstract}
A series of asymmetric cyanine dyes based on methylenoxy benzothiazole terminal heterocycle was synthesized. Absorption and fluorescent properties of these dyes and their complexes with nucleic acids were investigated. The best results were obtained with 2-I/3methyl-2(3H)-benzothiazolyliden)-methyl]-5,6-dioxymethylene-3-methylbenzothiaz olium p-toluenesulfonate (Cyan 13). A possible model of binding monomethyne benzthiazole cyanine dyes with double-stranded nucleic acids is proposed.
\end{abstract}

Introduction. The use of fluorescent cyanine dyes for the nonradioactive detection of nucleic acids increased dramatically in recent years because of their exceptional spectral properties. The polymethyne cyanine dyes have high extinction coefficients $\left(>70000 \mathrm{~mol}^{-1} \mathrm{~cm}^{-1}\right)$, moderate quantum yields $(0.08-$ 0.4 ) and good photostability [1]. When the polymethyne chain is lengthened by one vinylene unit, the absorption maximum is shifted to longer wavelength by about $100 \mathrm{~nm}$. This relationships allows to obtain dyes with fluorescence emission in the near infrared (IR) region, thus facilitating a significant improvement of the signal-to-noise ratio, permitting their potential use as fluorescent probes for the analysis of DNA, lipids, peptides, and proteins [2]. Cyanines have relatively narrow emissions bandwidths, making them useful for multicolour applications in the DNA labelling [ 3 ].

These cationic dyes have very high binding affinity to double-stranded (ds) DNA, single-stranded (ss) DNA and RNA [4]. Their fluorescent intensity magnify an orders when they bound to nucleic acids [5]. Since no separation step is necessary with this property (homogeneous labelling), determination can be carried out relatively easy in the presence of unbound dye. This principle was used by Pitner et al. to design cyanine labelled oligonucleotide probes for «in-solution» hybridization [6].

Unsymmetrical cyanine dyes, thiazole orange dimer TOTO $\left(1,1^{\prime}-(4,4,7,7-\right.$ tetramethyl-4,7-diazaundeca-methylene)-bis-4- [3-methyl-2,3-dihydro-(benzo1,3-thiazole)-2-methyl-idene -quinolinium tetraiodide) and yellow orange dimer YOYO (an analogue with a benzo-1,3-oxazole in the place of benzo-1,3-

\footnotetext{
*Correspondence address.

(C) S. M YARMOLUK, V. B. KOVALSKA, T. V. SMIRNOVA, M. P. SHANDURA, Yu, P. KOVTUN,

G. Kh. MATSUKA, 1996
} 
thiazole) are the most sensitive DNA stain dyes currently available. A linear dependence of fluorescence intensity on DNA concentration over a range from 0.5 to $100 \mathrm{ng} / \mathrm{ml}$ allows sensitive quantitation of dsDNA in conventional spectrofluorymeter [7]. Glazer et al. have used these dyes for the detection and sizing of dsDNA in agarose gels [8], investigation of dsDNA binding proteins [9]. Others have used dimeric cyanines for the examination of static and dynamic properties of isolated DNA molecules [10] and for the investigation of DNA migration in capillary solution electrophoresis [11].

Interaction of cyanine dyes with nucleic acids occurs by intercalation mode. Jacobsen at al. have proposed model of binding of TOTO to dsDNA involving the insertion of a conjugated ring system into the interior of the helix, nestled between the adjacent base pairs of the DNA. It was shown that the binding of TOTO to larger oligonucleotides is site selective with CTAG:CTAG as preferred binding site $\{12\}$. Rye and Glazer proposed a partial intercalation model of TOTO binding to DNA to explain stability and spectroscopic properties of TOTO-ss DNA complexes [4].

This is the second report of our investigation specifying the preparations of cyanine dyes and their interactions with nucleic acids. Recently we have showed that monomethyne cyanine dyes with methylenoxy benzothiazole terminal heterocycle for highly fluorescent complexes with nucleic acids [13]. This study compares the NA-interaction of five new structurally like benzthiazole cyanines dyes in order to understand possible mode of interaction of cyanine dyes with dsNA.

Materials and Methods. Spectroscopic measurements. The absorption spectra were obtained on «SPECORD UV-VIS» spectrophotometer (Germany). Absorption of free dyes was measured immediately after dissolving of dimethylsulfoxide (DMSO) dye stock solution in appropriate: $50 \mathrm{mM}$ Tris- $\mathrm{HCl}$, $\mathrm{pH} 8$ or DMSO. Fluorescence spectra were recorded with a serial fluorescence spectrophotometer Hitachi Model 850 (Japan). All spectra were corrected by means of multiplying fluorescence intensities that measured over an interval of $5 \mathrm{~nm}$ by suitable correction factor for given wavelengths. In corrected spectra fluorescence intensity values were proportional to a numbers of photons per unit of wavelength interval. Fluorescence measurements were carried out in thermostatable quartz cell $(0.5 \times 0.5 \mathrm{~cm})$. Fluorescence was excited with a $150 \mathrm{~W}$ Xe-lamp emission.

Preparation of DNA, RNA and dyes stock solutions. Stock solution of dyes $\left(2 \cdot 10^{-3} \mathrm{M}\right)$ were prepared by dissolving dyes in DMSO. All dyes were stable under these conditions for several months, whereas in aqueous solutions some dyes gradually lost fluorescence properties. Working solutions were prepared immediately prior to use. For spectral studies total calf thymus DNA («Sigma») and yeast RNA («Sigma») were used. Nucleic acids stock solutions were prepared in TE buffer (Tris- $\mathrm{HCl}, 50 \mathrm{mM}$, EDTA, $10 \mathrm{mM}, \mathrm{pH} \mathrm{8.0}$ ) in concentration $6.1 \cdot 10^{-3}$ b. p. for DNA and $2.4 \cdot 10^{-2}$ b. p. for RNA.

Absorbance and fluorescent emission spectra. For spectral measurements the complexes of dyes with nucleic acids were obtained by mixing of dye stock solution with DNA or RNA solution in Tris- $\mathrm{HCl}(50 \mathrm{mM}, \mathrm{pH} 8.0)$ buffer. The final concentration of DNA an RNA was $1.2 \cdot 10^{-4}$ and $2.0 \cdot 10^{-4} \mathrm{mM}$ respectively. Final dyes concentrations were $0.02 \mathrm{mM}$. Dye-nucleic acid complexes were prepared with approximal ratio 1 dye per $10 \mathrm{~b}$. p. of RNA and per $6 \mathrm{~b}$. p. of DNA. For optical measurement of free cyanines the same dyes concentrations were used.

Preparation of cyanine dyes. The synthetic scheme for representative dyes are shown in Fig. 1. Standard procedures were used for the synthesis of unsymmetrical monomethyne cyanines [14]. The main reaction involved formation of dyes from quaternized benzothiazole salt with methyl or 


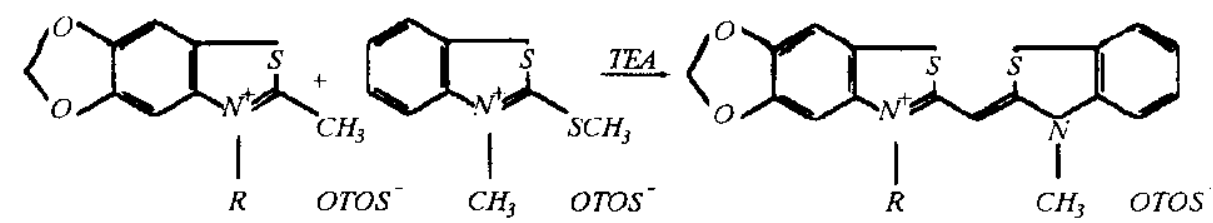

Fig. 1. Synthetic scheme for representative methylenoxybenzothiazole cyanine dyes. $\mathrm{R}=-\mathrm{CH}_{3}$; $-\mathrm{C}_{2} \mathrm{H}_{5} ;-\mathrm{C}_{3} \mathrm{H}_{7} ;-\mathrm{C}_{4} \mathrm{H}_{9}$

methylthiogroup of unsubstituted benzothiazolium salt. Cyan 15 was obtained according to $[15]$. The purity of synthesized dyes were controlled by UV-spectroscopy and elemental analysis.

Results. Dye structures and specroscopic properties of free dyes. Physical data for five synthesized cyanine dyes and TO are presented in Table 1. The fluorescent properties of these dyes have not been previously studied. Dye TO with well investigated spectral properties was included for the comparison [8]. The wavelengths of absorption maxima $\left({ }^{\mathrm{abs}} \lambda_{\max }\right)$ of benzothiazole cyanines slightly depend on solvent. Absorption maxima of the dyes showed the red shift of $5-10 \mathrm{~nm}$ after going from aqueous buffer to less polar DMSO. The extinction coefficients for all dyes are high $(3.3-9.06) \cdot 10^{4} \mathrm{M}^{-1} \mathrm{~cm}^{-1}$.

The fluorescence of free dyes is very low. All of these dyes have Stokes shift between 53 and $81 \mathrm{~nm}$.

NA-interaction properties of dyes. The data on the absorbance and fluorescence emission spectra of the NA-bound form of dyes are presented in Table 2. All dyes had short Stokes shifts $(26.0-84.0 \mathrm{~nm})$. Fluorescence spectra profile of DNA-bounded of symmetrical Cyan 45 is distinctive from the another dye-NA complexes (Fig. 2). Absorption and emission spectra of dye-nucleic acids complexes were measured at approximate ratio 1 dye per 6 base pairs for DNA and 1 dye per 10 bases for RNA.

Titration of cyan 13 and TO with DNA and RNA. Fluorescence titration of Cyan 13 and TO were carried out in $0.05 \mathrm{M}$ Tris buffer ( $\mathrm{pH} \mathrm{8)}$ with total calf thymus DNA and yeast RNA at $490 \mathrm{~nm}$ (for Cyan13) and at $534 \mathrm{~nm}$ (for TO). Fixed concentration of nucleic acid was used for the titration of fixed concentration of dye (Fig. 3). The dye concentration was $2 \cdot 10^{5} \mathrm{M}$. The DNA and RNA concentration was changed from $2.9 \cdot 10^{-6}$ to $4.1 \cdot 10^{-4}$ and from $1.1 \cdot 10^{-5}$ to $9.1 \cdot 10^{-4}$ respectively. For the Cyan 13-DNA complexes fluorescence plateau is reached at 4 base pairs per dye (A). Titration of RNA showed that the fluorescence emission per bound Cyan 13 reaches a maximum at 15 base/dye (B). Fluorescence intensity of Cyan 13 is $2-3$ fold greater than that for TO.

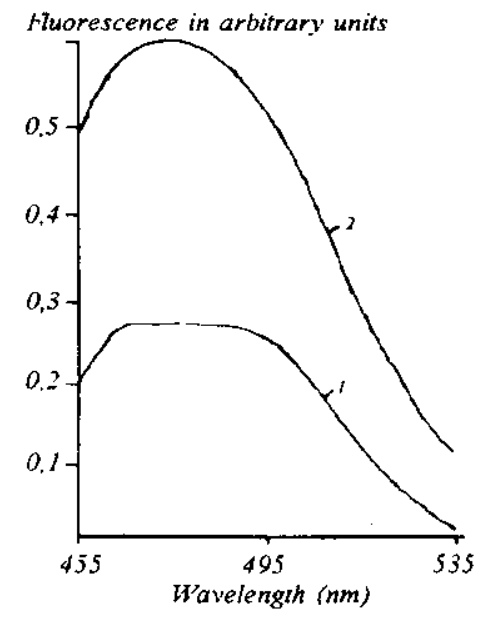

Fig. 2. Emission spectra of Cyan 45 complexes with DNA (I) and RNA (2) 
Table I

Chemical structures and spectroscopic properties of cyanines dyes

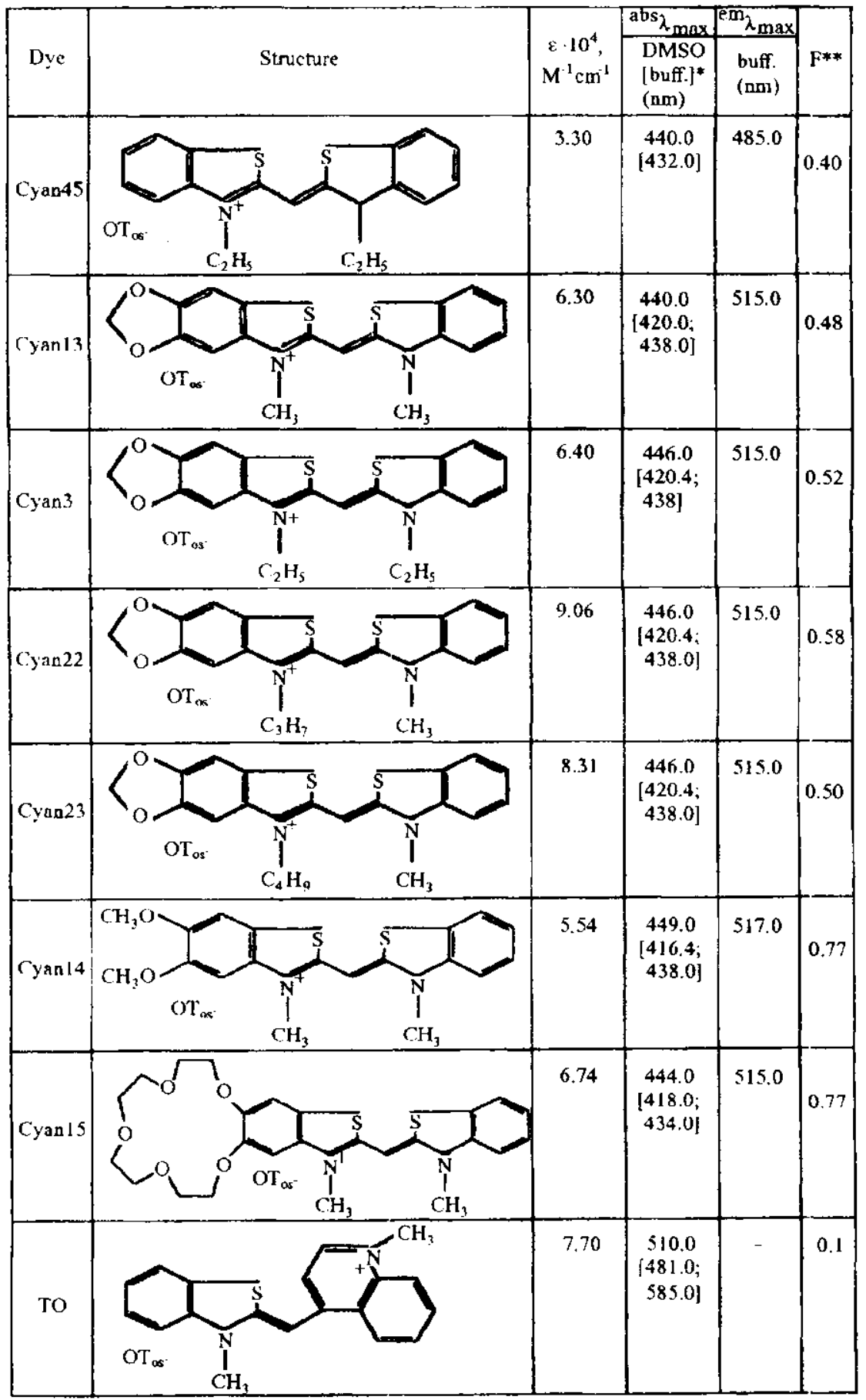

${ }^{*}$ The ${ }^{a b s} \lambda_{\max }$ values for dyes in buffer are subject to some error because of the tendency to form dye associates even at the low concentration; **Arbitrary units 
Table 2

Spectroscopic properties of cyanine dyes complexes with nucleic acids

\begin{tabular}{|c|c|c|c|c|c|c|c|c|}
\hline \multirow[t]{2}{*}{ Dye } & \multicolumn{4}{|c|}{ DNA-Dye Complex } & \multicolumn{4}{|c|}{ RNA-Dye Complex } \\
\hline & ${ }^{\mathrm{abs} \lambda_{\max ^{\prime}} \quad \mathrm{nm}}$ & ${ }^{e a_{\lambda}} \max _{x^{\prime}} \quad$ om & $\Delta S, \quad$ om & $\mathrm{RFI}_{\mathrm{TO}}{ }^{*}$ & ${ }^{\mathrm{abs}} \lambda_{\max }, \quad \mathrm{om}$ & 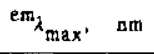 & $\Delta s . \quad n m$ & $\mathrm{RFI}_{\mathrm{TO}} \mathrm{O}^{\circ}$ \\
\hline \multirow[t]{2}{*}{ Cyan 45} & 407.0 & 472.0 & 43.0 & 0.86 & 410.0 & 470.0 & 39.0 & 1.68 \\
\hline & 427.0 & - & - & - & 431.0 & - & - & - \\
\hline \multirow[t]{2}{*}{ Cyan 3} & 429.0 & 496.0 & 52.0 & 1.73 & 444.0 & 494.0 & 50.0 & 1.73 \\
\hline & 444.0 & - & - & - & - & - & - & - \\
\hline \multirow[t]{2}{*}{ Cyan 13} & 423.0 & 486.0 & 44.0 & 2.60 & 430.0 & 489.0 & 36.0 & 2.80 \\
\hline & 442.0 & - & - & - & 453.0 & - & - & - \\
\hline \multirow[t]{2}{*}{ Cyan 22} & 423.0 & 485.0 & 43.0 & 1.86 & 431.0 & 489.0 & 36.0 & 1.85 \\
\hline & 442.0 & - & - & - & 453.0 & - & - & - \\
\hline \multirow[t]{2}{*}{ Cyan 23} & 423.0 & 486.0 & 44.0 & 1.19 & 431.0 & 491.0 & 38.0 & 1.15 \\
\hline & 442.0 & - & - & - & 453.0 & - & - & - \\
\hline \multirow[t]{2}{*}{ Cyan 14} & 397.0 & 481.0 & 84.0 & 0.86 & 403.0 & 487.0 & 41.0 & 1.34 \\
\hline & - & - & - & - & 446.0 & - & - & - \\
\hline \multirow[t]{3}{*}{ Cyan 15} & 400.0 & 487.0 & 50.0 & 1.19 & 424.0 & 485.0 & 41.0 & 1.83 \\
\hline & 416.0 & - & - & - & 444.0 & - & - & - \\
\hline & 458.0 & - & - & - & - & - & - & - \\
\hline TO & 490.5 & 534.0 & 26.0 & 1.00 & 490.0 & 542.0 & 34.0 & 1.00 \\
\hline
\end{tabular}

Relative fluorescence intensity $\left(\mathrm{RFI}_{\mathrm{TO}}\right.$ ) is the ratio of fluorescence intensities at the peak emission for the bound cyanine dye and the bound TO.

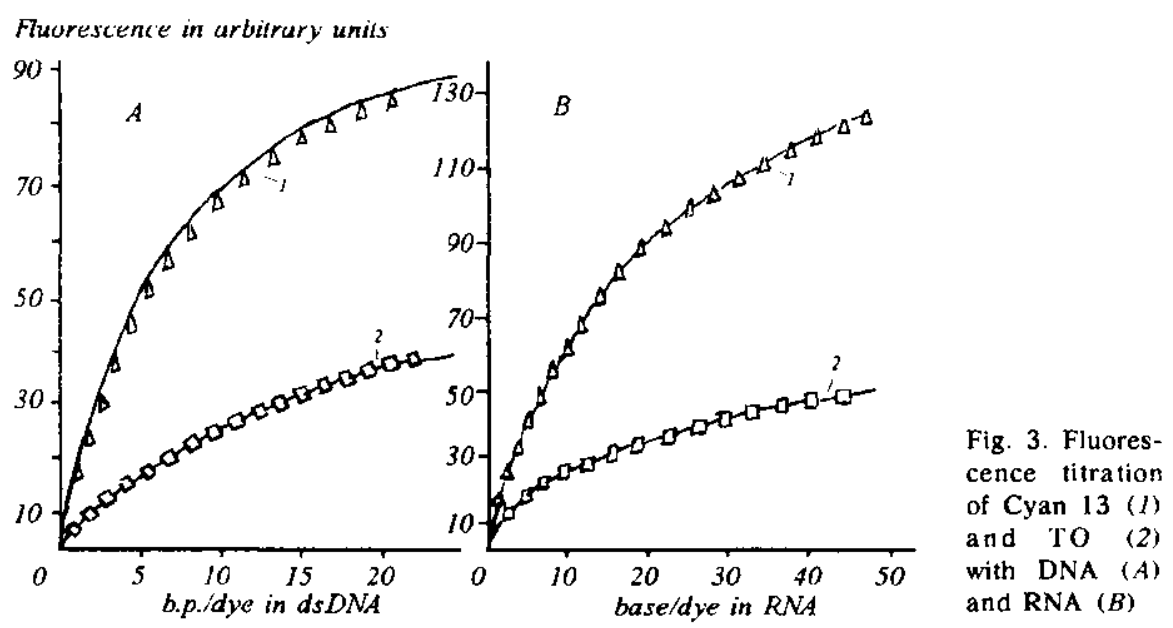

Discussion. In 1986, Lee et al. reported the use of some new dyes with structures like thioflavin $T$ as fluorescent probes in nucleic acids analysis. All of these dyes had a thiazolium or oxazolium moiety which were bridged with an aromatic amine nucleus (quinolinium, propidium or $p$-dimethylaminostyryl). TO, YO and PRO (propidium iodide) were found to have excellent properties for detection and quantitation of RNA and DNA. They have large molar absorbtivities $\left(70000-100000 \mathrm{M}^{-1} \mathrm{~cm}^{-1}\right)$, are virtually nonfluorescent in free 
form but show strong fluorescence when bound with RNA $(1000-3000$ fold enhancement [6]) and DNA (1000-1500 fold enhancement [5]).

We have previously showed that methylenoxybenzothiazole is perspective heterocycle for the development of new cyanine dyes for the nucleic acids detection. Cyan 3 formed highly fluorescent complexes with RNA and DNA with 600-fold fluorescent enhancement [13]. Here we present the series of new monomethyne cyanine dyes with methylenoxybenzothiazole terminal heterocycle like Cyan 3. Their fluorescence intensity is $1.2-3$-fold greater than that TO. Cyan 13 has the most promising characteristics for the nucleic acid analysis. Besides it has sufficiently low fluorescence in free state $(0.48)$.

The nature of interaction and the relative affinities of the cyanine dyes for various nucleic acid targets are unknown [4]. An understanding of the molecular mechanism by which monomethyne cyanines interact with nucleic acids is important, for several reasons. Such knowledge will be useful for designing probes that are more sensitive to structural distinctions of nucleic acids. Information concerning the mechanism of enhancement of fluorescence of bound dyes is likely to be useful for development of homogeneous detection methods of nucleic acids. With these thoughts in mind, we have focused our attention on the investigation of monomethyne benzothiazole cyanines which are structurally similar.

Jacobsen et al. used classical intercalation model of Lerman [16] to explain possible mode of interaction of TOTO with oligonucleotide duplexes. Their model demonstrated that TOTO bis-intercalates with the benzothiazole ring above the cytosin ring and the quinolinium ring system on the top of an adenosine base. Moreover it was emphasised that only proposed model of complex was in agreement with NMR data [12]. The data presented here do not suggest «classical» intercalation-full insertion of conjugated ring system into the interior of the NA-helix (compare Cyan 15 and Cyan 13).

Recently Rye and Glazer reported that polycationic dyes, such as TOTO and EtD (Ethidium bromide), capable of bis-intercalation, interact with dsDNA and ssDNA with very similar high affinity. In order to explain the extensive and stable association TOTO with homopolymers and ssDNA authors proposed the model of partially intercalated both thiazole head groups between the bases of a single DNA strand. This model was named a «partial intercalation-like» complex [4].

However this model of intercalation badly agrees with hypothesis of enhancement fluorescence intensity of dye upon binding with nucleic acids. It is considered that the enhancement is the result of decreased rotational mobility around the internuclear bridge between the two aromatic ring system of $\mathrm{TO}$ chromophore $[5,16]$. For dimeric dyes like TOTO the intercalation of thiazole head could led to the increased rigidity of dye system. But for monomeric dyes of only of thiazole head groups can not stabilise relative orientation of two heterocycles of TO.

We propose model of «half intercalation» monomethyne cyanine dye into the double-stranded helix. Benzothiazole terminal heterocycle «classically» intercalates, nestled between the adjacent base pairs just when second heterocycle is spatially fixed by groove of nucleic acid.

It is possible that electronic asymmetry of cyanine serves only for correct orientation of dye before intercalation. We consider that heterocycle with high basicity hits in the more nucleophilic groove whereas heterocycle with low basicity insert (i. e. intercalates) in more electrophilic interbase space.

All dyes presented here have less basic unsubstituted benzothiazole heterocycle as compared with second substituted one of cyanine. Increase of asymmetry of positive charge distribution results in increase of fluorescent intensity of NA-dye complexes (Fig. 4). Introduction of nucleophilic groups 


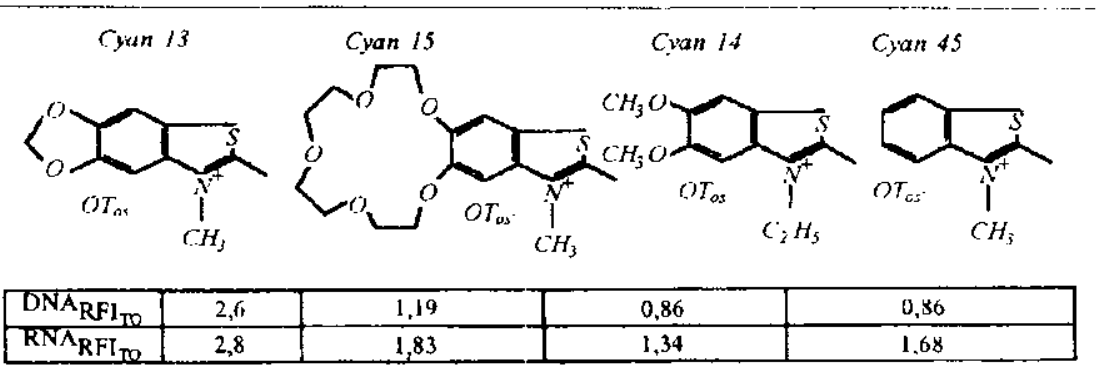

Fig. 4. Influence of basicity of second terminal heterocycle on the fluorescence intensity of NA-dye complexes. Basicity of heterocycle increases from Cyan 45 to Cyan 13

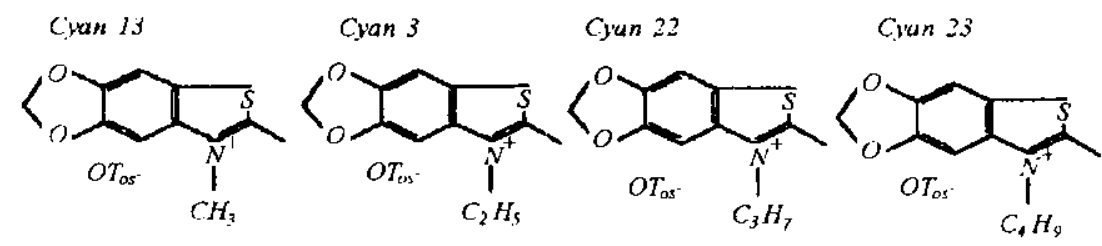

\begin{tabular}{|l|l|l|l|l|}
\hline $\mathrm{DNA}_{\mathrm{RFI}} \mathrm{T0}$ & 2,6 & 1,73 & 1,86 & 1,19 \\
\hline $\mathrm{KNA}_{\mathrm{RFI}_{\mathrm{T}}}$ & 2,8 & 1,73 & 1,85 & 1,15 \\
\hline
\end{tabular}

Fig. 5. Influence of length of alkyl chain attached to the nitrogen atom of benzothiazole nuclei on the fluorescence intensity of NA-dye complexes

$\left(\mathrm{SO}_{3}{ }^{-}, \mathrm{COO}^{-}\right)$in the intercalating benzthiazole heterocycle sharply decreases the intensity thiazole head of fluorescence (see Cyan 1, Cyan 4, Cyan 5 [13]).

Fluorescent intensity of NA-dye complexes, presented in Figure 4 depends upon structure of groove binding heterocycle. However Cyan 14 and Cyan 15 have similar fluorescence properties. Increase of length of $\mathrm{N}$-alkyl substituent decreases fluorescence intensity of NA-dye complex too (Fig. 5).

Apparently, structure changes of groove binding heterocycle do not sharply influence on intensity of fluorescence.

As indicated in the above discussion, the studies presented here have led to the development new monomethyne cyanine dyes for the high sensitivity detection of nucleic acids.

Acknowledgements. We are grateful to Drs A. Ishchenko and I. Dubey for valuable discussions. Author express their gratitude to Dr. Yu. Slominsky for the providing us with Cyan 13. The project is supported by National Academy of Sciences of Ukraine.

С. М. Ярмолюк, В. Б. Ковальська, Т. В. Смирнова, М. П. Иандура, Ю. П. Ковтун, Г. Х. Мацука

Взаємодія ціанінових барвнихів та нуклеїнових кислот. 2. Синтез та спектроскопічні властивості метиленоксианалогів тіазолового оранжевого

Резюме

Синтезовано серію асиметричних монометинових иіанінових барвників 3 метиленоксибензтіа золовим термінальним сетероциклом. Досліджено їх абсорбційні та флкоресцентні властиво сті, спектральні властивості їх комплексів з нуклеїновими кислотами. Найкращі результати одержані 3 n-толулолсульфонатом 2-I(3-метил-2(3Н)-бензотіазоліліден)метил]-5,6-диоксиметилен-3-метил-бензотіазолію. Пропонусться сіпотетична модель взасмодї монометинових бензтіазолових барвників з двоспіральними нуклейновими кислотами. 
INTERAC:TION OF CYANINE DYES WITH NUCLEIC: ACID

С. Н. Ярмолюк, В. Б. Ковальская, Т. В. Смирнова, Н. П. Нандура, Ю. П. Ковтун, Г. Х. Мацука

Взаимодействие цианиновых красителей и нуклеиновых кислот. 2. Синтез и спехтроскопические свойства метиленоксианалогов тиазолового оранжевого

Резюме

Синтезирована серия асимметричных монометиновых иианиновых красителей с метиленоксибензтиазоловым терминальным сетероциклом. Исследованы их абсорбционные и флюоресцентные свойства, спектральнье свойства их комплексов с нуклеиновыми кислотами. Наилучиие результаты получены с п-толулолсульфонатом 2-/(3-метил-2(3H)-бензотиазолилиден)метил1-5,6-диоксиметилен-3-метилбензотиазолия. Предлагается сипотетическая модель взаимодействия монометиновых бензтиазоловых красителей с двуспиральными нуклеиновыми кислотами.

\section{REFERENCES}

1. Haughland R. P. Molecular probes. Handbook of fluorescent probes and research chemicals, 1994 // Molecular probes. - Eugene: OR, 1994.

2. Soper S. A., Mattingly $Q$. L. Steady-state and picosecond laser fluorescence studies of nonradiative pathway in tricarbocyanine dyes: implications to the design of Nea-IR fluochromes with high fluorescence efficiencies // J. Amer. Chem. Soc.-1994.-116.-P. 3744-3752.

3. Rye H. S., Quesada M. A., Peck K., Glazer A. N. High-sensitive two-colour detection of double-stranded DNA with a confocal fluorescence gel scanner using ethidium homodimer and thiazole orange // Nucl. Acids Res. -1990 - 19.-P. 372-333.

4. Rye H. S., Glazer A. N. Interaction of dimeric intercalating dyes with single-strande DNA // Ibid. $-1995 .-23$. -P. $1215-1222$.

5. Lee G. I., Chen C. $-H$., Chiu $L$. A. Thiazole Orange: a new dye for reticulocyte analysis // Cytometry. $-1986 .-7 .-P .508-517$.

6. Pitner J. B., Mize P. D., Linn C. P. Synthesis and fluorescence properties of covalent thiazole orange-oligonucleotide conjugates // The 3th Int. symp. on functional dyes (July 16-21, 1995). - Santa Cruz, 1995.- P. 52.

7. Rye H. S., Dabora J. M. Fluorometric assay using dimeric dyes for double- and single-stranded DNA and RNA with picogram sensitivity // Anal. Biochem.-1993.-208.-P. 144-150.

8. Rye H. S., Yue S., Wemmer D. E. et al. Stable fluorescent complexes of double-stranded DNA with bis-intercalating asymmetric cyanine dyes: properties and applications // Nucl. Acids Res. - 1992.-20.-P. 2803-2812.

9. Rye H. S., Drees B. L., Nelson H. C. M., Glazer A. Stable fluorescent dye-DNA complexes in high sensitivity detection of protein-DNA interactions $/ / \mathrm{J}$. Biol. Chem. -i993.-268.P. 25229-25238

10. Goodwin P. M., Johnson M. E., Martin J. C. et al. Rapid sizing of individual fluorescently stained DNA fragments by flow cytometry // Nucl. Acids Res.-1993. - 21.—P. 803-806.

11. Carlsson C., Larsson A, Jonsson M., Norden B. Dancing DNA in capillary solution electrophoresis // J. Amer. Chem. Soc.-1995.-117.-P. 3871-3872.

12. Jacobsen J. P., Pedersen J. B., Hansen L. F., Wemmer D. E. Site selective bis-intercalation of a homodimeric thiazole orange dye in DNA oligonucleotides // Nucl. Acids Res. - 1995. - 23.P. $753-760$.

13. Yarmoluk S. M., Zhyvoloup A. N., Kovalska V. B et. al. Interaction of cyanine dyes with nucleic acids. I. Studies on monomethine cyanine dyes as possible fluorescent probes for the detection of nucleic acids // Biopolymers and Cell. $-1996 .-12, \mathrm{~N} 5 .-\mathrm{P}$. 50-55.

14. Hamer $F$. M. The cyanine dyes and related compounds.- New York; London: J. Willey, 1964. $-790 \mathrm{p}$.

15. Kovtun Yu. P., Shandura M. P., Tolmachev A. I. Polymethyne dyes with (benzo-15-crown5) thiazole moiety // Khim. Geterocykl. Soedin. (In press.)

16. Ishchenko A. A. Structure and spectroscopic properties of polymethyne cyanine dyes.-Kyiv: Nauk. dumka, 1994. -231 p. 